\title{
Assessment of Water Quality in Selected Dams in Machakos Municipality, Kenya
}

\author{
Gakaria Ngonyo Mercy Nzeve Julius Kioko \\ Department of Environmental Sciences, Machakos University, P.O. Box 136 - 90100, Machakos, Kenya
}

\begin{abstract}
The world is faced with a water quality crisis due to human activities that are putting a lot of pressure on water resources and especially dams and rivers. Dams are very much needed in arid and semi-arid areas to curb water scarcity so that local communities can have water for domestic use, watering of livestock and carrying out small scale irrigation. The aim of this study was to assess the water quality of Maruba dam and Kyai earth dam in Machakos Municipality, Kenya. The physical and chemical variables examined included $\mathrm{pH}$, chlorides, electric conductivity, turbidity, nitrites, nitrates, sulphates, phosphates and total dissolved solids. Water samples were collected using $500 \mathrm{ml}$ plastic bottles weekly for a month in the two dams and taken to the laboratory for analysis. Independent T-test was used to compare means of water quality parameters between the two dams and significant differences accepted at $p<0.05$. All the water quality parameters measured except turbidity were within WHO set standards for domestic water. The information gathered in this study is helpful to the Water Resource Authority that is mandated to protect and conserve water resources in Kenya.
\end{abstract}

Keywords: Water quality crisis, Maruba dam, Kyai earth dam, Machakos municipality

DOI: $10.7176 / \mathrm{JEES} / 11-10-04$

Publication date:October $31^{\text {st }} 2021$

\subsection{Introduction}

Fresh water is a precious resource that is essential for human health and sustainable development. However, like other natural resources, fresh water is being threatened by anthropogenic activities. This has resulted to water crisis even as the demand for water resources has continued to increase. According to the 2019 United Nations Sustainable Development Goals report, 785 million people globally lacked basic drinking water services in 2017 (UN, 2019). Two billion people live in countries experiencing high water stress, while 4 billion people experience severe water scarcity at least one month per year (UN, 2019). Kenya is a water-scarce nation with less than 1000 $\mathrm{m}^{3}$ per capita of renewable freshwater supplies (UN Water, 2006). The scarcity of water in Kenya has led to an increased number of dams being constructed by the government. Dams are barriers constructed to hold water for activities such as irrigation, domestic consumption and industrial use among other uses (Ndlela et at., 2017). Dams are very much needed in arid and semi-arid environments where water scarcity is a major challenge. Dam water provides economic, environmental and social benefits to local communities in Africa. These includes water supply for drinking, flood control, hydro-electric power, irrigation, aquaculture and recreation. However, there is a global water quality crisis as human activities continue to put pressure on water resources (Abbaspour, 2011). Water quality may change when watersheds or catchment areas are modified by human activities such as agriculture, municipal and industrial expansion. Water quality is an extremely important environmental factor as it affects humans and their economic activities. It is a major challenge that humanity is facing in the $21^{\text {st }}$ century. The nature and extent of human activities be it agricultural, domestic, industrial will determine the degree and nature of water quality status either on temporal or spatial scales. This deterioration in water quality and quantity impacts the availability of clean and safe drinking water for populations and also affects the aquatic ecosystem. According to WHO (2008), about one billion people have no access to safe drinking water resulting into water crisis.

Kenya's water resources face serious threats from pollution, siltation, reclamation, pesticides, weed attack, and human population activities (Nyanchaga, 2016). Water shortage has been a great encounter over the years especially for those people living within arid and semi-arid regions of Kenya. These are areas associated with low and unreliable rainfall and very high temperature during dry spell increasing the evaporation rates.

Small scale earth dams, boreholes and shallow wells have been used as sources of water. Earth dams also known as embankment dams are structures constructed across rivers or streams to create a reservoir behind themselves. They are constructed for rain harvesting to retain flood runoff during rainy season. Water from earth dams is not suitable for drinking without being subjected to treatment. A lot of siltation due to large amounts of sediment washed into the dams during severe storm makes the water turbid. Eutrophication as a result of high nutrient load for example phosphates and nitrates impair the beneficial use of water.

Machakos County is a water scarce County with its water situation levels below the national natural endowment of $647 \mathrm{~m}^{3}$ per capita per year. Its arid and semi-arid areas are critically limited in water endowment. To address the water scarcity situation, more investment in water storage infrastructure should be done to increase water storage per capita $(\mathrm{GOK}, 2018)$. Water resources in the County are mainly seasonal rivers and dams. In addition, several earth dams and springs across the County serve as water resources. Machakos town is served 
with piped water from Maruba dam that is located within the municipality. Increasing population and social economic activities within the town have caused high demand for water which stands at 22,315 cubic meters per day (Humphreys, 2018). The dam is fed with water from Manza stream which passes through urban settlements that include estates such as Miwani, Kenya Israel and lower Kiandani. Based on its location and the streams supplying water to the dam, there is need to ascertain its water quality and its implication to human health. Apart from Maruba dam, within the same locality is Kyai earth dam which supplies water to local communities living around Katelembo area. The water is used for domestic use, small scale irrigation, and watering of livestock. Regular water quality assessment of water resources is important to determine suitability and safety of varying purposes. Therefore, this study sought to assess the physicochemical characteristics of water from the two urban dams which is important in decision making on sustainable development within the catchment area of the two dams.

\subsection{Materials and Methods}

2.1 Study area

The study was carried out in two dams (Maruba and Kyai) that are located in Machakos town in Machakos County (Figure 1). Machakos town is 63 kilometers southeast of Nairobi and is about 1600 metres above sea level. Its population is rapidly growing and was 170,606 people as of 2019 census (KNBS, 2019). Machakos municipality is well drained by a number of seasonal rivers and streams which supply water to the two dams among others. On the East are the Iveti hills and on the West are the Mua hills. Machakos town lies between the two hills. The two dams are supplied with water by rivers and streams flowing from the two hills respectively. The town experiences both warm and cold seasons. March is the hottest month of the year while July is the coldest month with temperatures averaging 16.5 Degree Celsius. The maximum temperature annual mean is 22 Degree Celsius whereas the minimum temperature annual mean is 14 Degrees Celsius. The soils in Machakos town are well formed deep red friable clay which is a well-drained soil. Maruba dam is located about 4 Kilometers to the South West of Machakos town and has a storage water capacity of $2.45 \times 106 \mathrm{~m}^{3}$ (Humphreys, 2018). Raw water from the dam is abstracted and treated in a composite water treatment plant that is located 300 meters downstream before its pumped to storage tanks within the town. It's from the storage tanks the residents of Machakos town are supplied with water in different days of the week.

\subsection{Collection of water samples}

Three sampling points were identified at each dam (Maruba and Kyai), that is at the mouth, middle and at the outlet. Water samples were collected weekly and in triplicates at each sampling site in the month of January, 2020. Water samples were collected at $30 \mathrm{~cm}$ water depth using 500 milliliter plastic bottles. Immediately after sample collection, sample bottles were sealed with a lid and labelled to indicate date of sampling and the sampling site. The collected samples were then transported to the Water Resource Authority laboratory in Nairobi for analysis. Physio-chemical parameters ( $\mathrm{pH}$, electrical conductivity, Total Dissolved Solids) were measured on site using a multi parameter water quality kit. 


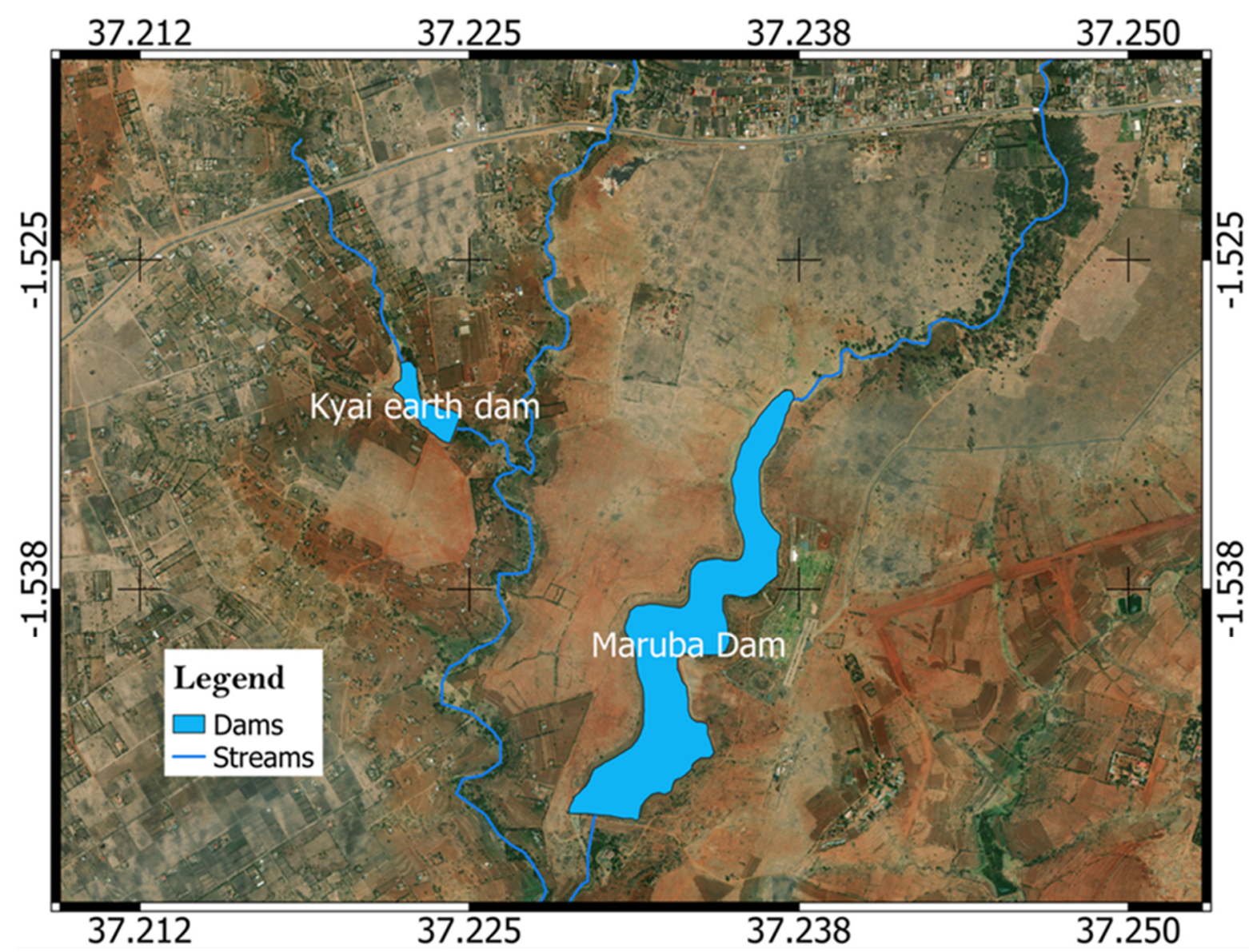

Figure 1: Map showing Maruba dam and Kyai earth dam in Machakos municipality, Kenya.

\subsection{Laboratory water analysis}

Water samples for phosphates, nitrates, nitrites, sulphates and chlorides were analyzed at the Water Resource Authority laboratory in Nairobi using standards procedures. Chloride was determined by titration method using silver nitrate and potassium chromate. Sulphates were determined by turbidimetric method while nitrites were determined by photometric method.

\subsection{Data analysis}

Data analysis was done using descriptive and inferential statistics. Independent T-test was used to compare significant differences $(\mathrm{p} \leq 0.05)$ for water quality parameters between the two dams. All the analyses were carried out using Statistical Package for Social Sciences (SPSS) software, version 21. The results were compared with WHO set standards for drinking water.

\subsection{Results and Discussions}

\subsection{Physicochemical Characteristics of Water}

The mean values of physico-chemical characteristics of water analyzed for the two earth dams are presented in Table1.

Table 1: Physico-chemical parameters of water in Maruba and Kyai earth dams

\begin{tabular}{|l|r|r|r|r|}
\hline Water Quality Parameter & \multicolumn{1}{c|}{ Maruba Dam } & \multicolumn{1}{c|}{ Kyai Earth Dam } & \multicolumn{1}{c|}{ p-value } & WHO Standards \\
\hline $\mathrm{pH}$ & $7.44 \pm 0.48$ & $7.52 \pm 1.03$ & 0.003 & $6.5-8.5$ \\
\hline Chlorides (mg/L) & $41.11 \pm 15.45$ & $59.44 \pm 9.61$ & 0.318 & $250 \mathrm{mg} / \mathrm{L}$ \\
\hline Conductivity (mg/L) & $244.67 \pm 54.04$ & $352.44 \pm 54.01$ & 0.710 & $1000 \mathrm{mg} / \mathrm{L}$ \\
\hline Nitrite (mg/L) & $0.14 \pm 0.18$ & $0.19 \pm 0.08$ & 0.076 & $3 \mathrm{mg} / \mathrm{L}$ \\
\hline Turbidity (NTUs) & $297.30 \pm 194.61$ & $36.92 \pm 24.24$ & 0.001 & $5 \mathrm{NTUs}$ \\
\hline Sulphates (mg/L) & $221.57 \pm 149.48$ & $29.19 \pm 18.13$ & 0.001 & $500 \mathrm{mg} / \mathrm{L}$ \\
\hline TDS (mg/L) & $151.69 \pm 33.50$ & $218.52 \pm 33.48$ & 0.710 & $1000 \mathrm{mg} / \mathrm{L}$ \\
\hline Nitrates (mg/L) & $2.79 \pm 1.51$ & $2.51 \pm 2.56$ & 0.070 & $50 \mathrm{mg} / \mathrm{L}$ \\
\hline Phosphates (mg/L) & $0.03 \pm 0.03$ & $0.03 \pm 0.04$ & 0.712 & - \\
\hline
\end{tabular}


Table 2: Physico-chemical parameters of water in Maruba earth dam

\begin{tabular}{|l|r|r|r|r|r|}
\hline $\begin{array}{l}\text { Water quality } \\
\text { parameter }\end{array}$ & Sampling site A & Sampling site B & Sampling site C & $\begin{array}{l}\text { Minimu } \\
\text { m }\end{array}$ & $\begin{array}{l}\text { Maximu } \\
\text { m }\end{array}$ \\
\hline Chloride (mg/L) & $38.00 \pm 3.60$ & $35.33 \pm 11.02$ & $50.00 \pm 25.24$ & 28.00 & 79.00 \\
\hline EC (mg/L) & $241.67 \pm 43.29$ & $201.00 \pm 32.51$ & $291.33 \pm 57.08$ & 177.00 & 344.00 \\
\hline Nitrites (mg/L) & $0.32 \pm 0.21$ & $0.01 \pm 0.01$ & $0.10 \pm 0.08$ & 0.00 & 0.56 \\
\hline TDS (mg/L) & $149.83 \pm 26.84$ & $124.62 \pm 20.16$ & $180.63 \pm 31.67$ & 109.74 & 213.28 \\
\hline Nitrates (mg/L) & $1.71 \pm 2.28$ & $3.56 \pm 0.90$ & $3.10 \pm 0.98$ & ND & 4.30 \\
\hline Phosphates (mg/L) & $0.06 \pm 0.03$ & $0.01 \pm 0.00$ & $0.00 \pm 0.00$ & ND & 0.09 \\
\hline
\end{tabular}

Table 3: Physico-chemical parameters of water in Kyai earth dam

\begin{tabular}{|l|r|r|r|r|r|}
\hline $\begin{array}{l}\text { Water quality } \\
\text { parameter }\end{array}$ & Sampling site A & Sampling site B & Sampling site C & $\begin{array}{l}\text { Minimu } \\
\text { m }\end{array}$ & $\begin{array}{l}\text { Maximu } \\
\text { m }\end{array}$ \\
\hline Chloride (mg/L) & $53.67 \pm 16.44$ & $62.00 \pm 4.36$ & $62.67 \pm 2.08$ & 35.00 & 67.00 \\
\hline EC (mg/L) & $302.67 \pm 25.50$ & $339.00 \pm 31.43$ & $415.67 \pm 6.66$ & 277.00 & 423.00 \\
\hline Nitrites (mg/L) & $0.19 \pm 0.03$ & $0.25 \pm 0.12$ & $0.14 \pm 0.02$ & 0.12 & 0.39 \\
\hline TDS (mg/L) & $187.65 \pm 15.81$ & $210.18 \pm 19.49$ & $257.71 \pm 4.13$ & 171.74 & 262.26 \\
\hline Nitrates (mg/L) & $5.74 \pm 1.18$ & $0.94 \pm 0.81$ & $0.82 \pm 0.79$ & $\mathrm{ND}$ & 6.56 \\
\hline Phosphates (mg/L) & $0.04 \pm 0.04$ & $0.05 \pm 0.04$ & $0.00 \pm 0.00$ & $\mathrm{ND}$ & 0.09 \\
\hline
\end{tabular}

\section{$3.2 \mathrm{pH}$}

The mean $\mathrm{pH}$ concentration in the two dams are shown in the Table 1 . There was significant variation $(\mathrm{p}=0.003)$ in $\mathrm{pH}$ concentration between the two dams. Mean $\mathrm{pH}$ concentration values were $7.44 \pm 0.48$ (Maruba) and $7.52 \pm 1.03$ (Kyai), and were all within the limit recommended by WHO guidelines of drinking water. The $\mathrm{pH}$ mean values for the different sampling sites in the two dams are presented in Figure 2. The mean $\mathrm{pH}$ among the sampling sites ranged from 6.50 to 7.82 in Maruba dam and 6.10 to 8.41 in Kyai earth dam. pH is an important water quality parameter because it influences many processes in natural water resources. Extreme $\mathrm{pH}$ values can affect the palatability of water and also cause corrosion of water distribution systems. $\mathrm{pH}$ influences the effectiveness of chlorine disinfection and by extension the level of microbiological quality of water (Oyhakilome et al., 2012). For effective disinfection $\mathrm{pH}$ should be less than 8 . The $\mathrm{pH}$ concentrations obtained in the two dams compare well with results (7.66 \pm 0.54$)$ obtained at Kalundu dam, in Kitui town, Kenya (Nzeve and Matata, 2021).

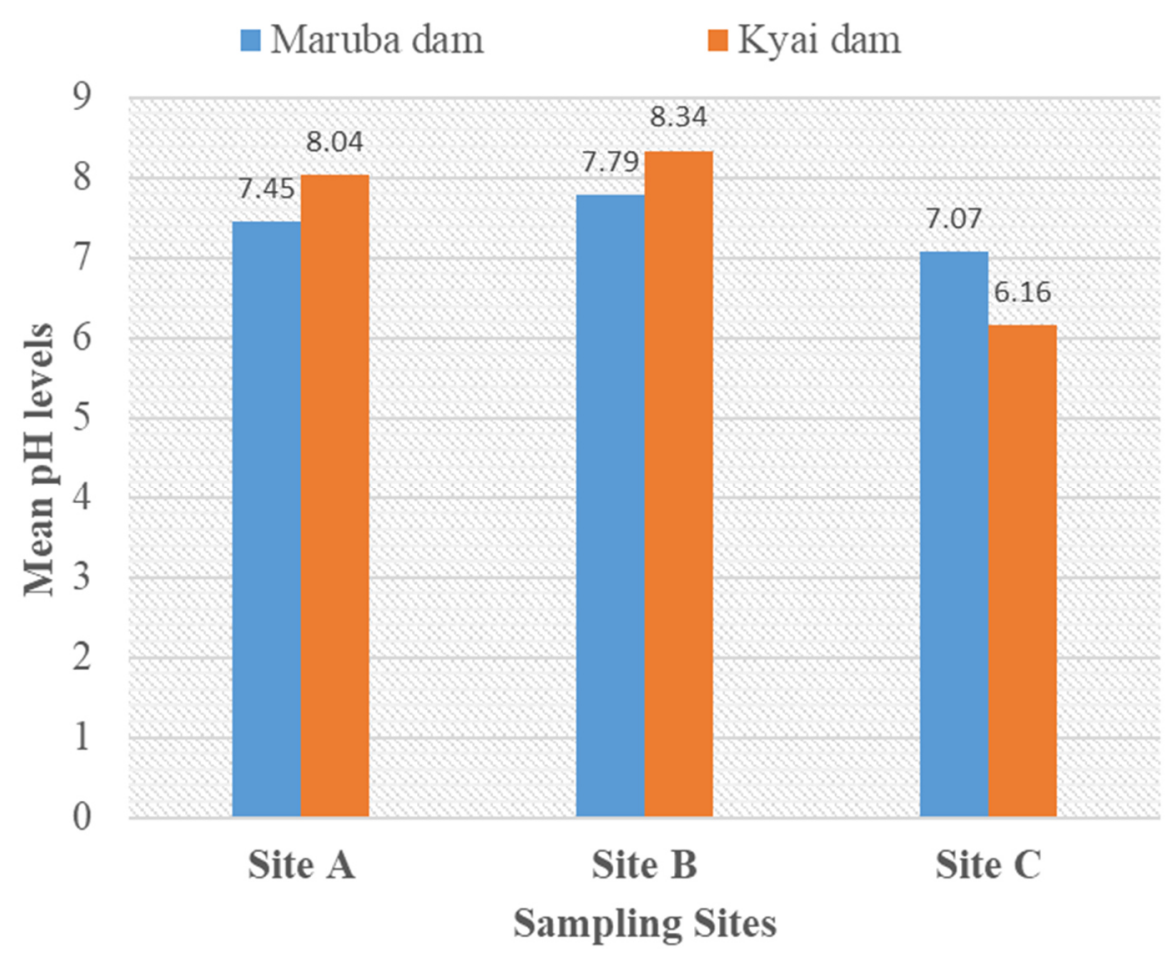

Figure 2: Mean $\mathrm{pH}$ concentrations in different sampling sites 


\subsection{Chlorides}

Chloride in drinking water may originate from natural sources, urban run-off, sewage and industrial effluent (WHO, 2011). There was no significant difference $(\mathrm{p}=0.318)$ in chloride concentration between the two dams. The mean values for chloride concentration were $41.11 \pm 15.45 \mathrm{mg} / \mathrm{L}$ (Maruba) and $59.44 \pm 9.61 \mathrm{mg} / \mathrm{L}$ (Kyai). This was below the $250 \mathrm{mg} / \mathrm{L}$ WHO set standards for drinking water (WHO, 2011). The mean Chloride concentrations within different sampling sites in the two dams is presented in Tables 2 and 3. The chloride concentrations recorded in the two dams were below those recorded by Nzeve and Matata (2021) in Kalundu dam in Kitui town, Kenya. High concentrations of chloride in excess of $250 \mathrm{mg} / \mathrm{L}$ can give rise to a salty taste in water (WHO, 2011).

\subsection{Electrical Conductivity}

Electrical conductivity (EC) is due to dissolved mineral ions in water. The mean EC concentration in the dams did not vary significantly $(\mathrm{p}=0.710$ ) and were $244.67 \pm 54.04 \mathrm{mg} / \mathrm{L}$ and $352.44 \pm 54.01 \mathrm{mg} / \mathrm{L}$ for Maruba dam and Kyai dam respectively. High specific conductivity causes deterioration hence unsuitable for domestic purposes. Relatively higher electrical conductivity in surface waters are associated with high chloride, phosphate and nitrate concentrations (Sainato et al., 2012). The mean EC concentrations for the different sampling sites in the two dams are presented in tables 2 and 3. The high levels of EC in this study can be associated with the agricultural activities within the catchment of the two dams.

\subsection{Nitrites}

There was no significant variation $(\mathrm{p}=0.076)$ in nitrite concentration in the two dams. The mean values of nitrites observed in Maruba dam was $0.14 \pm 0.18 \mathrm{mg} / \mathrm{L}$ and Kyai dam was $0.19 \pm 0.08 \mathrm{mg} / \mathrm{L}$. The concentration of different forms of nitrogen are an indication of the level of micronutrients in water and hence their ability to support plant growth. The mean concentration levels among the different sampling sites in the two dams are as presented in Tables 2 and 3. The nitrite levels ranged from BDL to $0.56 \mathrm{mg} / \mathrm{L}$ in Maruba dam and 0.12 to $0.39 \mathrm{mg} / \mathrm{L}$ in $\mathrm{Kyai}$ dam. The presence of nitrites in surface waters is an indicator of sewage pollution and major concern due to its toxicity (WHO, 2008). The streams that supply the two dams with water pass through urban settlements and therefore a possibility of point source pollution from sewage septic tanks. Nitrite levels in unpolluted surface waters exists below $0.03 \mathrm{mg} / \mathrm{L}$ (WHO, 2008). Nitrite is extremely toxic to aquatic life such as fish for it causes impairment of oxygen transport which leads to anoxia and mortality (Palachek and Tomasso, 1984).

\subsection{Turbidity}

Turbidity in water is an indication of the presence of suspended matter or colloidal matter and hence it's a reflection of overall quality of water. This is caused by inorganic or organic matter or a combination of the two (WHO, 2011). There was significant difference in variation of the two dams $(p=0.001)$. In the present study, the mean values of turbidity concentration were 297.30 \pm 194.61 NTUs and 36.92 \pm 24.24 NTUs for Maruba dam and Kyai earth dam respectively. The mean turbidity levels at the different sampling sites within the two dams are presented in Figure 3. The turbidity levels during the sampling period ranged from 15.74 to 476 NTUs in Maruba dam and 11.94 to 74 NTUs in Kyai earth dam. The turbidity levels in the two dams was way above the recommended WHO set standards of 5 NTUs for drinking water (WHO, 2008). The high turbidity levels are an indication of high siltation within the catchments of the two dams. This could be due to poor farming practices within the catchment. High turbidity can lead to an increased amount of disinfection by products that form in treated water and interfere with sunlight penetration (Oyhakilome et al., 2012). The high levels of turbidity in Maruba dam are due to siltation within the catchment on the side of Iveti hills. This leads to poor raw water from the dam before its treatment and subsequent supply to the residents of Machakos town for drinking and other domestic use. As a result, large quantities of Aluminum sulfate is used in the treatment plant for coagulation. Again, a lot of water with high amounts of coagulants is channeled downstream from the treatment plants, thus causing more water quality deterioration in the riverine ecosystem. Water quality deterioration due to catchment degradation makes it expensive to treat the water for domestic use, maintain the water treatment facilities and reservoirs (World Bank, 2006). High turbidity levels can seriously interfere with efficiency of disinfection by providing protection to organisms (WHO, 2011). Therefore, turbidity is a hazard that should be controlled to minimize treatment costs for municipal water supplies. Turbidity levels should be maintained below 1NTU to ensure effective disinfection of surface water (WHO, 2011). 


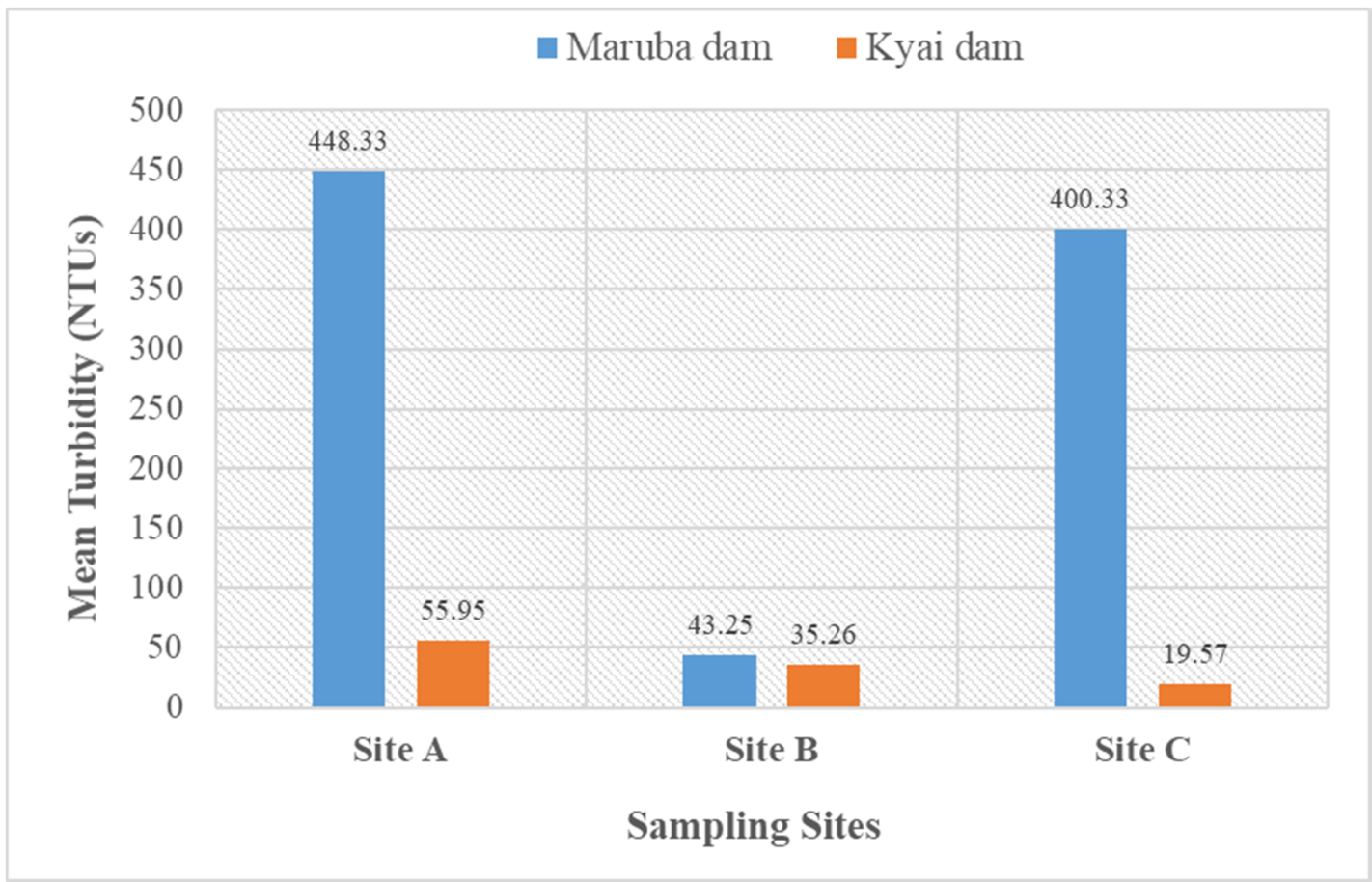

Figure 3: Mean Turbidity levels at different sampling sites

\subsection{Total Dissolved Solids}

Concentration of Total Dissolved Solids (TDS) in water is an essential parameter that determines the quality of drinking water. Higher value of TDS is potentially unhealthy for aquatic life. There was no significant difference in variation $(\mathrm{p}=0.710)$ in TDS concentration in the two dams under study. The mean values of TDS were $151.69 \pm 33.50 \mathrm{mg} / \mathrm{L}$ and $218.52 \pm 33.48 \mathrm{mg} / \mathrm{L}$ for Maruba dam and Kyai dam respectively. The mean TDS levels recorded during the study for different sampling sites are presented at Table 2 and 3. The TDS levels recorded were below the WHO set standards for drinking water. TDS in drinking water originates from natural sources, sewage, urban runoff and industrial wastewater.

\subsection{Sulphates}

There was significant difference in variation $(\mathrm{p}=0.001)$ in sulphate concentration in the two dams. Sulphate occurs naturally in water as a result of leaching. The mean values of sulphate concentration were $221.57 \pm 149.48 \mathrm{mg} / \mathrm{L}$ for Maruba dam and $29.19 \pm 18.13 \mathrm{mg} / \mathrm{L}$ for Kyai earth dam. This was within the acceptable tolerance limit of $500 \mathrm{mg} / \mathrm{l}$. Figure 4 shows the mean sulphate levels at the different sampling sites within the two dams. The presence of sulphates in drinking water in excess of $500 \mathrm{mg} / \mathrm{L}$ may cause noticeable taste and corrosion of water distribution systems (WHO, 2011). 


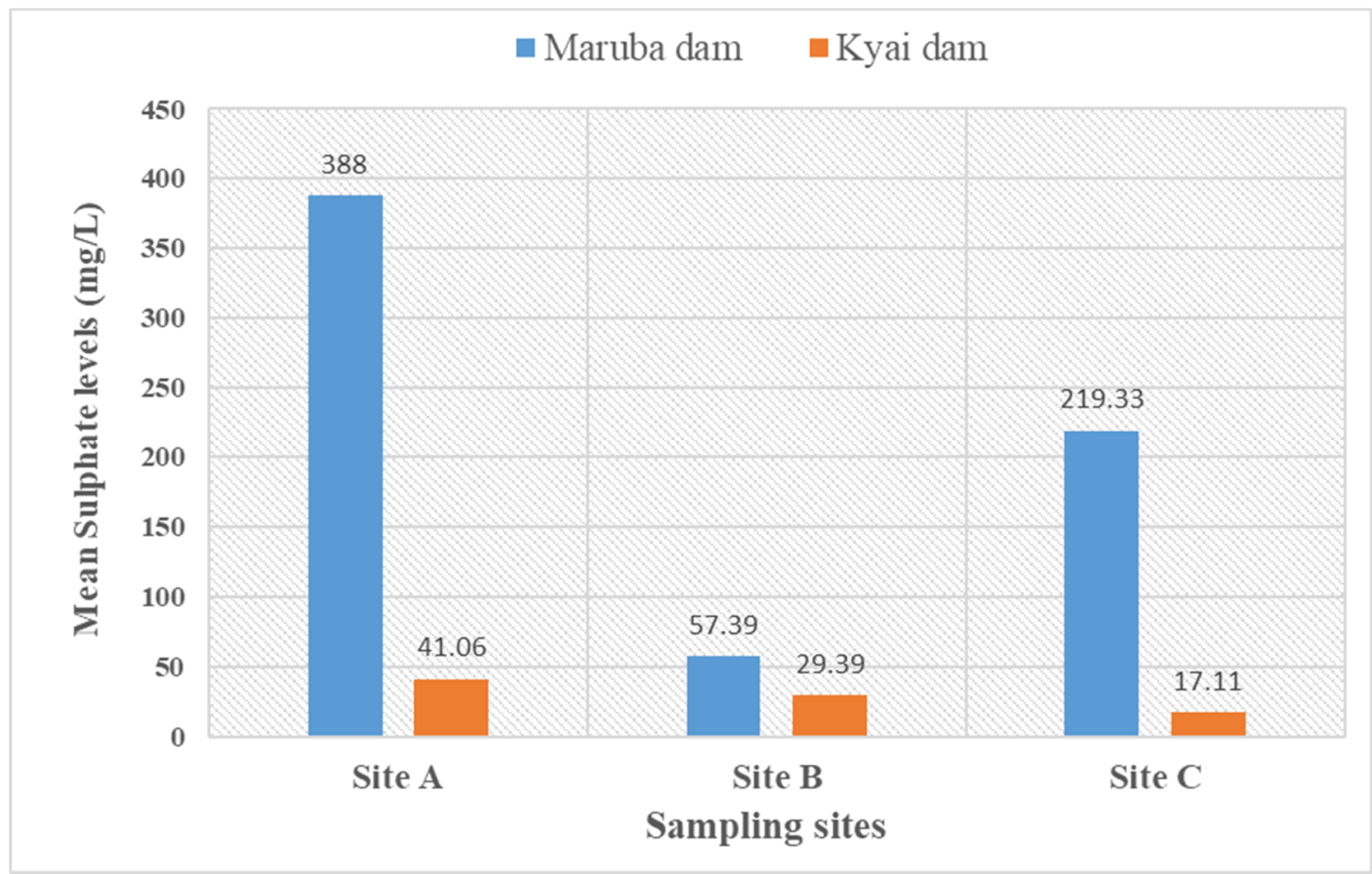

Figure 4: Mean Sulphate levels at different sampling sites

\subsection{Nitrates}

The main source of nitrate is decomposition of organic matter, application of agricultural fertilizers, waste water disposal and oxidation of nitrogenous waste products in animal and human excreta, including septic tanks (WHO, 2011). Assessing nitrate concentration is important in drinking water because of health of humans and animals. The presence of nitrates in reservoir suggests bacterial growth. There was no significant variation $(p=0.070)$ in nitrates concentration. The mean values of nitrate concentration in the two dams were $-2.79 \pm 1.51 \mathrm{mg} / \mathrm{L}$ (Maruba) and $2.51 \pm 2.56$ (Kyai). This was below the WHO recommended levels of $50 \mathrm{mg} / \mathrm{L}$ for drinking water (WHO, 2011). The mean nitrates levels for different sampling sites in the two dams are presented in Tables 2 and 3. High nitrate levels in drinking water have negative effects to infants as the they are converted to nitrites which reacts with blood hemoglobin leading to methaemoglobinaemia (Sidhu and William, 2000).

\subsection{Phosphates}

There was no significant variation $(\mathrm{p}=0.712)$ in phosphate concentrations. The mean values of phosphate were $0.03 \pm 0.03 \mathrm{mg} / \mathrm{L}$ in Maruba) and $0.03 \pm 0.04 \mathrm{mg} / \mathrm{L}$ for Kyai earth dam. Phosphates occur widely in nature in plants, microorganisms and in animal wastes. It is highly used as an agricultural fertilizer. Excess amount of phosphates may lead to eutrophication in aquatic systems. Typically, the concentrations of phosphates in unpolluted surface waters ranges between $0.001 \mathrm{mg} / \mathrm{L}$ to $0.3 \mathrm{mg} / \mathrm{L}$ (Oyhakilome et al., 2012).

\section{Conclusion and Recommendations}

The study concluded that the water quality parameters measured except turbidity were within WHO set standards for domestic water. The higher levels of turbidity within the two dams is an indication of poor farming practices leading to soil erosion and accumulation of silt within the two dams. Siltation leads to reduction water volume that the dams can hold at any given time. This is costly to the county government that is mandated to supply adequate and quality water to the residents of Machakos town. Therefore, the study recommends that the concerned government departments and agencies especially Water Resource Authority, National Environment Management Authority and Department of Agriculture should take the necessary measures to curb soil erosion within the catchment. The study recommends further research of bacterial loads both in the two dams and the enjoining streams. The study also recommends awareness creation on good farming practices especially to the farmers within the catchment.

\section{Acknowledgements}

The authors appreciate Water Resources Authority (WRA), Nairobi for availing their laboratory facility during analysis of water samples. 


\section{References}

Abbaspour, S (2011). Water quality in developing countries, South Asia, South Africa, Water quality Management and activities that cause water pollution. 2011 International Conference on Environmental and Agriculture Engineering IPCBEE vol.15(2011) C) (2011) IACSIT Press, Singapore

Government of Kenya (2018). Machakos County Integrated Development Plan, 2018 - 2022.

Humphreys, H (2018). Machakos Water and Sanitation 'Design and Build' Project. Environmental and Social Impact Assessment Study Report for Machakos Town Water Supply Project.

KNBS (2019) 2019 Kenya Population and Housing Census, Volume II: Distribution of Population by Administrative Units. KNBS, Nairobi.

Ndlela, Z. P., Vilane, B.R. T and Nkambule, N. F (2017). An assessment of the Mvutjini Earth Dam Water quality at Kalanga, Swaziland. Journal of Agricultural Science and Engineering Vol. 3, No. 1, 2017, pp. 13-19

Nyanchaga, E. N (2016). The history of water supply and governance in Kenya (1895-2005). Lessons and Futures. Tampere University Press https://doi.org/10.26530/OAPEN 610992

Nzeve, J.K and Matata, A. M (2021). Assessment of Water Quality in Kalundu Stream and Kalundu dam in Kitui County, Kenya. Journal of Environment and Earth Science, Vol.11, No.1, 2021, pp 36 - 40

Oyhakilome, G. I., Aiyesanmi A. F, and Akharaiyi F. C (2012). Water Quality Assessment of the Owen Multi-

Purpose Dam, Ondo State, Southwestern Nigeria. Journal of Environmental Protection, 2012, 3, 14-25 http://dx.doi.org/10.4236/jep.2012.31003

Palachek, R. M and Tomasso, J.R (1984) Toxicity of Nitrite to Channel Catfish (Ictalurus punctatus), Tilapia

(Tilapia aurea) and Largemouth Bass (Micropterus salmoides): Evidence for a Nitrite Exclusion Mechanism," Canadian Journal of Fish and Aquaculture Science, Vol. 41, No. 12, 1984, pp. 1739-1744. doi:10.1139/f84214

Sainato, C.M., Losinno, B.N, Malleville, H.J (2012). Assessment of contamination by intensive cattle activity through electrical resistivity tomography. Journal of Applied Geophysics. 2012; 76:82-91. http://dx.doi.org/10.1016/j. jappgeo.2011.10.010

Sidhu and William (2000). Chemistry of the Environment, 2nd Edition, published by Prentice Hall or India Private Limited, New Delhi.

UN World Water Development Report (2006) 2nd UN World Water Development Report.

United Nations (UN) (2019). Sustainable Development Goals Report, 2019. United Nations, New York 2019. Retrieved from www.un.org on August 26, 2021.

World Bank (2006) Climate Variability and Water Resources Degradation in Kenya-Improving Water Resources Development and Management (Working Paper No. 69). World Bank, Washington D.C.

World Health Organization, "Guidelines for Drinking - Water Quality," 3rd Edition, World Health Organization, Geneva, 2008.

WHO (2011). Guidelines for drinking water-quality. 4th edition, Geneva, Switzerland. 